\title{
Child Development in Institutions of Abepura Publicity, Jayapura City
}

\author{
Yeheschiel Bartin Marewa ${ }^{1}$, Liberthin Palullungan ${ }^{2}$, Nurhabri $^{3}$ \\ Dept.of Law, Universitas Kristen Indonesia Paulus (UKIP) Makassar,Indonesia 1,2,3 \\ \{marewa@ukipaulus.ac.id ${ }^{1}$, liberthin@ukipaulus.ac.id²\}
}

\begin{abstract}
The purpose of this article is to know and understand about the process of guiding correctional students in the correctional institutions at the Abepura Jayapura Community Service Institution. The type of this research is juridical normative which is sourced from primary and secondary and tertiary materials, which are analyzed qualitatively by describing the results of the existing data descriptively. The results of the study provide an illustration that the development of correctional students in the Class Iia Abepura Correctional Institution is carried out with the first stage of guidance followed by assimilation then integration with the hope that after serving a period of punishment students can return to society and society can accept it but that in the implementation of coaching there are obstacles faced by the officer. Obstacles are divided into two parts, namely internal factors, namely prisoners, facilities and infrastructure, budget / funds and human resources (supervisors) then external factors are lack of coordination with supervisory judges, supervisory prosecutors and correctional institutions.
\end{abstract}

Keywords: Development; correctional institutions; Judges and Prosecutors

\section{Introduction}

\subsection{Definition and Age Limit of Child Criminality}

Prodjodikoro shows the existence of the father and mother of the child in the sense that as a result of the act of intercourse from a man and a woman, a woman is born from another human's body, that the man is the father and the woman is the mother., while he is the child of both parents[1]. Wadong "the location of a child in a legal environment as a legal subject, is determined by the form and system of the child as a community group that is in legal status and classified as incapacitated or underage"[2]. R. Soepomo states the characteristics of maturity measurements as follows:
a. Can work alone; [3]
b. Competent and responsible in society;
c. Can manage their own assets;
d. Married;
e. 16 years old. 
Article 1 paragraph 1 of Law Number 3 Year 1997 Regarding Juvenile Justice as follows "A child is a person who in the case of Naughty Children has reached 8 (eight) years but has not reached the age of 18 (eighteen) years and has never been married". .Soemitro,[4]-[5]. Suhardjo to treat inmates treated as the basis of the correctional system, namely: That not only is the community protected against repeated evil acts by the convicted person, but also by people who have gone astray are protected by providing them with provisions to live as useful citizens in societ[6]. From the protection, it is clear that imposing punishment is not an act of revenge from the state. Repentance cannot be achieved by torture, but by guidance. The convict is also not sentenced to torture, but rather the punishment of losing his independence. The state has taken the liberty of a person who in time will return that person to society again, has obligations towards that convicted person and society.

The protection provided by the Criminal Code (KUHP) for human dignity still follows the convicted person into a correctional institution. Mardjono Reksodiputro, [7]. According to the correctional system, the development of inmates (Petrus Irwan Panjaitan and Pandapotan Simorangkir, [8] includes 2 (two) parts, namely:

a. General education

b. Skills courses

c. Recreation, sports, arts

d. Scouting

e. Work training

f. Assimilation

Law Number 23 Year 2002 concerning Child Protection, formulates and determines age limits that: "A child is a person who has not reached the age of 18 (eighteen) years, including children who are still in the womb" (Article 1 Number 1). [9] Soekito describes the definition or definition of children in several countries with the following age levels[10].

"In the United States, 27 states have an age limit of 8-18 years, while 6 states have an age limit of 8-17 years, there are other states that have an age limit of 8-16 years. In the UK it has an age limit of 12. -16 years. Australia, in most states determines the age limit between 8-16 years. The Netherlands sets the age limit between 12-18 years. ASEAN countries, among others, the Philippines sets the age limit between 7-16 years. Malaysia determines the age limit 7-18 years old Singapore determines an age limit of 7-16 years ".

Soemitro [11] is described as follows: "the provisions of the 1945 Constitution, the regulation is affirmed by the issuance of Law Number 4 of 1979 concerning Child Welfare", which means the meaning of children (the definition of children), namely a child must obtain rights which are then -this right can guarantee proper growth and development both spiritually, physically and socially. Or children are also entitled to services to develop their abilities and social life. Children are also entitled to care and protection both during pregnancy and after birth. Siregar and Nusantara [12] stated: "The law must focus on children's rights in general, and in the criminal justice process in particular, it will be highlighted as a social study and children who have committed criminal acts (child delinquency) so that individual backgrounds and backgrounds can be assessed the causes of criminal offenses ".

\subsection{Community Office}

With the provisions of Law Number 3 of 1997 concerning Juvenile Court, the provisions of duties and social workers, as well as Prayuwana institutions are still functioning, but their names are changed to community officers. From article 33 it is determined that social officers consist of: 
a. Community advisor from the Ministry of Justice;

b. Social workers and the Ministry of Social Affairs;

c. Volunteer social workers from Community Social Organizations.

Community officers also work as found in case examination at all levels of the judiciary. From the results of the examination, which is sometimes carried out by observing, making conclusions, making suggestions, etc., they have the same authority as other law enforcement officials. The specialty of community officers is to provide psychological and medical considerations to children who commit delinquency or are victims of crime.

The purpose of mentoring correctional clients is to shape the prisoners to become real people or completely human beings and can realize their mistakes to improve themselves and are expected not to repeat criminal acts again. Furthermore, the people assisted by the correctional facilities can live naturally as good and responsible citizens of the community and can return to the community to participate in development. With the provisions of Law Number 3 of 1997 concerning Juvenile Court, the provisions of duties and social workers, as well as Prayuwana institutions are still functioning, but their names are changed to community officers. From article 33 it is determined that social officers consist of:

a. Community advisor from the Ministry of Justice;

b. Social workers and the Ministry of Social Affairs;

c. Volunteer social workers from Community Social Organizations.

Community officers also work as found in case examination at all levels of the judiciary. From the results of the examination, which is sometimes carried out by observing, making conclusions, making suggestions, etc., they have the same authority as other law enforcement officials. The specialty of community officers is to provide psychological and medical considerations to children who commit delinquency or are victims of crime.

The purpose of mentoring correctional clients is to shape the prisoners to become real people or completely human beings and can realize their mistakes to improve themselves and are expected not to repeat criminal acts again. Furthermore, the people assisted by the correctional facilities can live naturally as good and responsible citizens of the community and can return to the community to participate in development.

\subsection{Correctional Institutions and Functions}

The definition of the correctional system according to Article 1 of Law Number 3 of 1997 is: "The penitentiary system is an order regarding the direction and boundaries, as well as the way of fostering prisoners, katan based on Pancasila which is carried out in an integrated manner between the coach, the fostered, and the community to improve the quality of the prisoners in order to realize mistakes, improve themselves and not repeat criminal acts so that they can be accepted back by the community, can play an active role in development, and can live as good and responsible assisted citizens ". The criminal justice system is a crime control system consisting of the police, prosecutors, courts, and correctional facilities for the convicted person. Mardjono Reksodiputro, [13]. Penitentiary can be said to have 4 (four) main functions, Shanti Dellyana, [14] namely:

a. Protect (protective)

b. To punish (punitive)

c. Repair (revormative)

d. Rehabilitate

This the court has decided that:

a. a person who violates will be given guidance on his behavior for a certain period of time; 
b. freedom will be limited for a certain period of time;

c. changes in values, attitudes and behavior are desirable;

d. experience with prisons will reduce the desire to commit violations of the law

\subsection{Principles and Rights of Child Prisoners in Correctional Institutions}

In accordance with Article 5 of Law Number 3 Year 1997 [15] it is implemented based on the following principles: $a$. the principle of protection, $b$. the principle of equality of treatment and service, c. Principles of Education, d. principles of development, e. the principle of respect for human dignity, f. the principle of losing the freedom of the only suffering, g. the principle of relating to certain families or persons. Advocacy for child protection according to Wahyono and Rahayu [16] is legal aid (defense) provided to protect the interests of children as perpetrators of crimes and violations (child delinquency) and also children as victims of acts against the law or criminal acts (kindermoor). by others.

\subsection{Special Guidance for Children according to the Law on the Juvenile Justice System}

A number of legal instruments specifically regulating child development have not comprehensively provided special protection for children who are in conflict with the law. Therefore it is necessary to have a paradigm shift in the handling of children who are faced with the law, such as the role and duties of the community, government and other state institutions that are obliged and responsible for improving children's welfare and providing special protection to children who are in conflict with the law.

The issuance of Law Number 11 of 2012 concerning the Criminal Justice System for Children in lieu of Law Number 3 of 1997 concerning Children's Courts which is expected to provide guarantees for the protection of the best interests of children who are in conflict with the law and aims to repair or restore (to restore) acts. crimes committed by children with actions that are beneficial for the child, the victim and the environment.

Law Number 11 of 2012 concerning the Criminal Justice System for Children, including the placement of children who undergo the judicial process can be placed in the Special Child Development Institution (LPKA) and strict regulations regarding "Restorative Justice" and "Diversion" which are intended to avoid and keep children away from the judicial process so as to avoid stigmatization of children who are in conflict with the law and it is hoped that children can return to the social environment naturally.

\section{Methodology}

This type of research is juridical normative which is sourced from primary and secondary and tertiary materials, which are analyzed qualitatively by describing the results of the existing data descriptively.

\section{Resulats and Discussion}

3.1 Child Development at the Abepura Prison, Jayapura City

\subsubsection{Development Stage}


Basically all prisoners are treated the same except in terms of supervision. Supervision here is closely related to the development stages. Each prisoner must start the stage of his guidance according to the correctional system. The stages of coaching the prisoner are determined by the length of the sentence imposed on the prisoner. Furthermore, it is said that in the development process for students according to the Decree of the Minister of Justice (now the Minister of Law and Human Rights) of the Republic of Indonesia Number: M.02PK.04.10 of 1990 concerning the Patterns of Guidance for Prisoners/Detainees, including:

a. The first stage, from admission to at least $1 / 3$ of the actual sentence.

b. The second stage, from $1 / 3$ to at least half of the actual sentence.

c. The third stage, from $1 / 2$ to $2 / 3$ of the actual criminal period.

d. The fourth stage, from $2 / 3$ until the completion of the criminal period.

There are 3 stages in the coaching process for students whose remaining prison term is up to one year, namely:

a. The first stage; since being received until at least half of the actual criminal period.

b. The second stage; since $1 / 2$ to at least $2 / 3$ of the actual sentence.

c. The third stage; from $2 / 3$ of the actual criminal period to completion.

\subsubsection{Form of Development}

The form of correctional guidance must be based on the Decree of the Minister of Justice (now Law and Human Rights) of the Republic of Indonesia Number M.02-PK.04.10 of 1990 concerning the Patterns of Guidance for Prisoners / Detainees. Based on the decree, the form of guidance carried out at Abepura Class IIA Penitentiary includes six main activities of guidance, including:

\section{a) Legal Counseling}

Legal counseling is provided to shape the behavior of prisoners so that they have legal awareness and obey the law while in the coaching environment and after returning to society. Extension activities are held face-to-face with extension agents in the form of a legal awareness meeting and connection through lectures, discussions, workshops, talks, demonstrations and legal simulations.

\section{b) Spiritual Education}

The spiritual counseling activities provided to inmates include religious education and general education, the implementation of which can be provided by prison officials or in cooperation with agencies related to spiritual counseling.

\section{c) Intellectual Ability Development}

Development of intellectual abilities is given with the aim of increasing the knowledge and thinking skills of the prisoners so that they can support the positive activities needed during the coaching period in the correctional institution.

\section{d) Physical Education}


Physical counseling is given to prisoners with the aim of maintaining the prisoners' physical health. Activities provided can be in the form of sports and recreation activities in accordance with the facilities available in the correctional facility.

\section{e) Talent and Skills Coaching}

Talent and skills guidance is given from the first stage (orientation). Providing guidance after the prisoners' talents are known then the prisoners will be directed to develop these talents.

\section{f) Library Development}

Library development is given to all prisoners and at the initial stage until the prisoner leaves the correctional facility or has served the entire prison term. This library development is provided with the aim of channeling the inmates' reading interest and the reading material is provided in the form of books, both books on religion and books of general, vocational knowledge and other books that are considered useful for inmates.

According to the types of criminal acts committed by child prisoners who are serving their sentence in a prison class IIA Abepura based on the types of criminal offenses committed, the following will be described in a table form as follows:

Table 1. Number of Child Prisoners in Abepura Class IIA Penitentiary according to the type of crime committed

\begin{tabular}{clcc}
\hline No & Classification of Crime & Total & Percentage \\
\hline 01 & Decency & 2 & 22,22 \\
02 & Kidnapping & 1 & 11,11 \\
03 & Persecution & 4 & 44,45 \\
04 & Theft & 2 & 22,22 \\
\hline \multicolumn{2}{c}{ Total } & 9 & 100,00 \\
\hline
\end{tabular}

Source: Abepura Penitentiary, processed March 2019

\subsection{Factors that influence the development of children in the Abepura Correctional Institution, Jayapura City}

\subsubsection{Internal Factors}

The prison class IIA Abepura as a supervisory institution is obliged to protect the rights and provide guidance to 226 prisoners with a correctional capacity of 230 people. There are 128 adult prisoners, with the following details: 9 child prisoners and 6 foreign convicts, while the prisoners are 194 adults, 26 children and 6 foreigners. This number has increased compared to 2013. (Penitentiary data source, March 2019). The following will describe the factors that influence the prison class IIA Abepura not maximally implementing the rights of prisoners as follows:

\section{a) Convict}

The obstacles faced by the correctional institution that originate from the internal institution itself are from the prisoners themselves. the lack of seriousness of prisoners in receiving or following the pattern of guidance and skills training that is routinely carried out. 
The result or impact of this lack of seriousness is that convicts who have been released or have served a sentence are unable or unskilled in applying the skills that have been taught while serving a sentence in prisons.

\section{b) Facilities and infrastructure}

The facilities and infrastructure owned by the Abepura Class IIA prison are still very limited. This can be seen from the lack of tools for the learning process and skills training, such as: libraries, mass media facilities, workshops.

\section{c) Budget / funds}

The most basic problem is the lack of budget (funds) to meet the needs of guidance and training. This is evident from several skills training activities which are mostly not carried out. Furthermore, on the same occasion an interview was also conducted with Luisa Hutagalung as a prison officer, saying that skills activities are no longer being carried out due to lack of funds to buy raw materials for making tela stone, wood skills and electrical installations.

\section{d) Correctional Officer}

Prison officers with minimal experience, minimal education and unprofessional work are also problems in the context of implementing the development and protection of prisoners' rights. Prison officers are mostly high school graduates or equivalent and some even have not finished high school education. Based on the level of education, it can be concluded that not all of them as prison officers know and understand the pattern of training prisoners or detainees in prisons.

\subsubsection{External Factors}

\section{a) Coordination of correctional institutions with supervisory and observing judges.}

Based on the provisions regarding the supervision of judges on the implementation of decisions, judges' decisions and the implementation of crimes in prisons can be controlled by the supervisory and observing judges. Judges who supervise and observe will be closer to prosecutors and correctional institution officials so that the wasmat judge can know the development of the convict so that the rights of the convicted person can be exercised. In carrying out their duties as supervisory and observing judges, the supervisory and observing judges must carry out the details of their duties as follows:

1. Checking and signing the supervisory and observation register which is at the clerk of the district court;

2. Conduct checking on the spot at least once every three months to the correctional institution to check the accuracy of the official report on the implementation of court decisions signed by the prosecutor, the head of the correctional institution and the convict;

3. Conducting observations of the conditions, atmosphere and activities that take place within the walls of the institution, in particular to assess whether the condition of the correctional facility has fulfilled the notion that punishment is not intended to distress 
and is not allowed to demean human dignity and observe with one's own eyes. the behavior of the prisoner in connection with the punishment imposed on him;

4. Conducting interviews with correctional officers (especially guardians of the prisoners concerned) regarding the behavior and outcomes of the prisoners, both the progress they have made and the setbacks that have occurred;

5. Conducting direct interviews with prisoners regarding their rights to treat themselves, human relations between themselves and with prison officials;

6. Contact the head of a correctional institution and the chairman of the correctional guidance board and if deemed necessary also contact the correctional coordinator at the regional office of the Ministry of Law and Human Rights in order to exchange suggestions, opinions in solving a problem and consult in a coordinative atmosphere regarding the procedures for treating prisoners of a technical nature both the treatment system inside the institutional wall and outside.

Basically, the implementation of supervision and observation by the supervisory judge and observer is in relation to the benefits for prisoners in particular and the criminal court in general. Among others

1. The work of the supervisory and observer judge is very useful for the judge in an effort to streamline the punishment because the effectiveness of the punishment can only be seen after the criminal decision can actually be implemented.

2. The results of the work of the supervisory judge and observer are very beneficial for the implementation of the duty of guiding the convicted judge because the duty of the supervisory judge and observer is not only to supervise and observe the implementation of the judge's decision but also to discuss matters related to the development of a certain convict with the head of the correctional institution;

The successful implementation of the duties of the supervisory and observer judges is largely determined by the cooperation of all components of the criminal justice system and the good and complete administration of criminal court administration.

The obstacle encountered in the prison class IIA abepura is that the role of the supervisory judge and observer is not properly carried out in accordance with their duties and authorities as described above. This was revealed from the results of the author's interview with a prison officer on behalf of Wilson Sibarani on March 15, 2019, who said that the role of the supervisory judge and observer was never known and felt in the Abepura Class IIA penitentiary.

\section{b) Correctional coordination with the correctional center}

Article 34 of the Child Protection Law requires horizontal coordination between the correctional facilities and the correctional institutions. This provision contains three main relationships, namely: The assimilation stage, The leave stage before being released, and The parole stage. These three stages require social research (litmas) as stipulated in Article 34 paragraph (1) letter a, that the social adviser is tasked with helping to smoothen the duties of investigators, public prosecutors and judges in cases of delinquent children, both inside and outside the children's trial by making research reports. .

The establishment of litmas by the Correctional Center when the Correctional Institution requests, then the Bapas will propose to the correctional institution the main things related to considerations of clients, but these matters are only limited to suggestions. The intended proposal does not affect the policy of the correctional institution but is attempted to be taken into consideration in assimilation measures, pre-release leave and parole that will be taken or 
taken by the correctional institution for the child perpetrators of a criminal offense. The proposal note to the correctional institution is to order the child concerned to undergo the process of assimilation, leave before release and parole and under the guidance of the correctional center. In substance, community research contains the following points:

1. Client identity consisting of: Client identity and The identity of the client's parent / guardian

2. Client problems which consist of: The background of the problem, Problems against the law committed by clients, and As a result of actions performed by clients

3. CVs of clients

4. Handling the client's future

5. The state of the client's family

6. The condition of the community environment

7. Responses consisting of: The response of the client's parents, Local community response, Local government response, and The response of the victim

8. Conclusions and suggestions

The Correctional Center based on the request for litmas can ask the agency requesting litmas main things related to the consideration of child clients, but this is only a recommendation. The proposal which is meant not to influence the prison policy but is attempted to be taken into account in assimilation, pre-release leave and parole that will be taken or taken by the prison against children who are in conflict

Constraints faced by the Abepura Class IIA Penitentiary in the framework of conducting guidance and protection of prisoners' rights. Therefore the correctional institution is trying to find a solution for the benefit of all parties. The results of the author's interview with the prison official, Mrs. Luisa Hutagalung, said that the class IIA Abepura prison did its best to try to fulfill the rights of prisoners. The fulfillment of prisoners' rights has been provided in accordance with the availability of funds, available infrastructure, such as musical instruments for entertainment during the celebration of national days and religious holidays.

\section{Conclusion}

Based on the discussion of the research results above, several conclusions can be drawn as follows:

a. Guidance for children in a prison class IIA Abepura is carried out in four stages, namely: (1) maximum security; (2) medium security; (3) minimum security, (4) integration. All of them have their own strategies and coaching objectives in the context of realizing the rehabilitation and resocialization process is not optimal.

b. Factors that influence the development of children in the prison class IIA Abepura are internal factors, including: (1) prisoners, (2) facilities and infrastructure, (3) budget / funds, (4) prison officers, external factors, among others: the coordination between the correctional institution and the supervisory and observer judges, coordination between the correctional institution and the correctional office (bapas) which does not run optimally.

\section{Acknowledgment}


The author expresses his appreciation to Universitas Kristen Indonesia Paulus for supporting the publication of this article.

\section{References}

[1] Prodjodikoro.1981. Establishing Criminal Law. Bina Aksara, Jakarta.

[2] Wadong. 2000. Several Comparative Problems of Criminal Law. PT. Raja Grafika Persada, Jakarta.

[3] R. Supomo (C.I. Harsono. 1995). New System of Development of Prisoners, Djambat, Jakarta.

[4] Law of the Republic of Indonesia. Number 3 of 1997 concerning Juvenile Justice. Article 1 paragraph (1), 2008. Jakarta: Sinar Grafika Offset.

[5] Soemitro. 1998. A Brief Overview of Indonesia's Criminal System. Pressindo Academy, Jakarta.

[6] Sahardjo, Change of Purpose of Guiding Prisoners, Speech in Inauguration as Doctor Honoris Causa, Jakarta, July 15, 1963.

[7] Mardjono Reksodiputro. Indonesian Criminal Justice System, (Looking at Crime and Law Enforcement Within the Boundaries of Tolerance) Speech inauguration of Permanent Professor of Faculty of Law, Ul Jakarta, 30 October 1993.

[8] Petrus Irwan Panjaitan and Pandapotan Simorangkir. 1995. Correctional Institutions in the Perspective of the Criminal Justice System, Jakarta.

[9] Law of the Republic of Indonesia. 23/2002 concerning Child Protection Article 1 Paragraph (1). 2008.Jakarta: Sinar Grafika Offset

[10] Soekito. 1988. Indonesia's Criminal and Criminal System. Pradnya Paramita, Jakarta.

[12] Siregar Nusantara. 1986. Conditional Criminal Institution. Alumni, Bandung.

[14] Shanty Dellyana. 1988. Women and Children in the Eyes of Law, Liberty, Jogyakarta.

[16] Wahyono and Rahayu. 1993. Correctional System in Indonesia. Liberty, Jogjakarta. 